\title{
Contribution of X-Ray Diffraction in the Identification of Crystalline Phases of the Mineralization Hosted in the Mesozoic Cover of the Tazzeka Hercynian Massif - Maghrawa Region - Morocco
}

\author{
Naoufal Saoud ${ }^{1,2, *}$, Issam Derkaoui ${ }^{3,4}$, Jaouad Choukrad ${ }^{1,2}$, Mohamed Amine El Moussalim², \\ Mohamed Charroud ${ }^{2}$

\begin{abstract}
${ }^{1}$ Laboratory of Intelligent Systems, Georesources \& Renewable Energies (SIGER), Faculty of Science and Technology of Fez, Sidi Mohammed Ben Abdellah University- Fes, Morocco

${ }^{2}$ Department of Research \& Development - ATLAS MINING, 03 Street Ait Ourir, BD Mly Youssef, Csablanca, Morocco

${ }^{3}$ Laboratory of Solid State Physics, Group of Nanomaterials and Renewable Energies, Faculty of Sciences Dhar el Mahraz, University Sidi Mohammed Ben Abdellah, PO Box 1796, Atlas, Fez, 30 000, Morocco

${ }^{4}$ Africa Graphene Center, Department of Physics, Eureka Building, College of Science, Engineering and Technology, Science Campus, University of South Africa, Cnr Christiaan de Wet \& Pioneer Avenue Florida, 1709, Johannesburg, South Africa
\end{abstract}

Received June 26, 2020; Revised October 20, 2020; Accepted October 30, 2020

\section{Cite This Paper in the following Citation Styles}

(a): [1] Naoufal Saoud, Issam Derkaoui, Jaouad Choukrad, Mohamed Amine El Moussalim, Mohamed Charroud, "Contribution of X-Ray Diffraction in the Identification of Crystalline Phases of the Mineralization Hosted in the Mesozoic Cover of the Tazzeka Hercynian Massif - Maghrawa Region - Morocco," Universal Journal of Geoscience, Vol. 8, No. 3, pp. 54 - 67, 2020. DOI: 10.13189/ujg.2020.080302.

(b): Naoufal Saoud, Issam Derkaoui, Jaouad Choukrad, Mohamed Amine El Moussalim, Mohamed Charroud (2020). Contribution of X-Ray Diffraction in the Identification of Crystalline Phases of the Mineralization Hosted in the Mesozoic Cover of the Tazzeka Hercynian Massif - Maghrawa Region - Morocco. Universal Journal of Geoscience, 8(3), 54 - 67. DOI: 10.13189/ujg.2020.080302.

Copyright $(2020$ by authors, all rights reserved. Authors agree that this article remains permanently open access under the terms of the Creative Commons Attribution License 4.0 International License

\begin{abstract}
Geological Research and prospection, mining exploration, remote sensing, geochemical methods, and geophysical technologies could improve the effectiveness and productivity of mineral exploration and ore identification. The application of these kinds of technologies presents the key factor of the future mining discoveries across the world. In this paper, we present the case study that consists to the use of geological investigation, remote sensing and geochemical studies in order of describing and determinizing the mineral fraction occurred in the Liasic series of Tazekka that manifests as carbonates cover of the Hercynean basement of the eastern Mesetean domain of Morocco. In fact, the followed procedure assigns the handling of remote sensing maps related to the area study, where we focus the hydrothermal alteration whichever allows the determination of selective and representative sample stations. Note that the collected
\end{abstract}

samples were subjected for two kind of geochemical analysis, when the first consists to the determination of mineral tenors using Inductive Coupled Plasma (ICP), and the second corresponds to the examination of samples by powder X-Ray Diffraction (XRD) methods in order to provide useful information about sample composition in terms of quantification of crystalline phases and content. In this work, we make in evidence the existence of remarkable mineralization of base and precious metals. These results may present an economic discovery in term of the potentiality of the Liasic cover of Tazekka for the mining exploration.

Keywords Technology, Mineral, Exploration, Remote Sensing, Hercynean, Tazekka, Morocco, ICP, XRD 


\section{Introduction}

The Zone study is located into northeast of the Hercynean basement of Tazekka massif, based in the northeast end of the Middle Atlas of Morocco, and especially in the Mesozoic cover that outcrops SW of Taza (Fig. 1). In the Tazekka, the mineralization occurs in the Hercynean massif, as veins, and stratiform in the Liasic cover [2-4]. The basement, appears as a lower Ordovician epimetamorphic schists, surmounted by volcano sedimentary complex dated Upper Visean-Namurian [5-7].

Note that magmatic rocks as kind of granite and microdiorite, are generally enclosed by an aureole of contact metamorphism [8].

The Mesozoic formations are represented by Triassic and Liassic rocks (Fig. 1), resting in discordance on the hercynean basement [9]. The Triassic serie starts with two formations of red argillites separated by a volcanic formation [3]. The lower and upper Triassic argillites show a huge hydraulic fracturing. The Lower Lias assigns three formations where the lowest consists of fine, massive, and dark dolomites [4].

The middle, presents a series of dolomitic breccias, laminated dolomites and crystalline dolomites, and the upper formation consists of pale grey, fine-grained limestone and dark grey limestone with oolitic and bioclastic intervals [3]. The Middle Lias consists of a series of interbedded limestones and marls, however, the Upper Lias-Aalenian and Lower Bajocian are generally marly [3]. In the Middle Atlas Causse domain, there's an unconformity between the lower Lias and upper formations of the center and upper Lias.
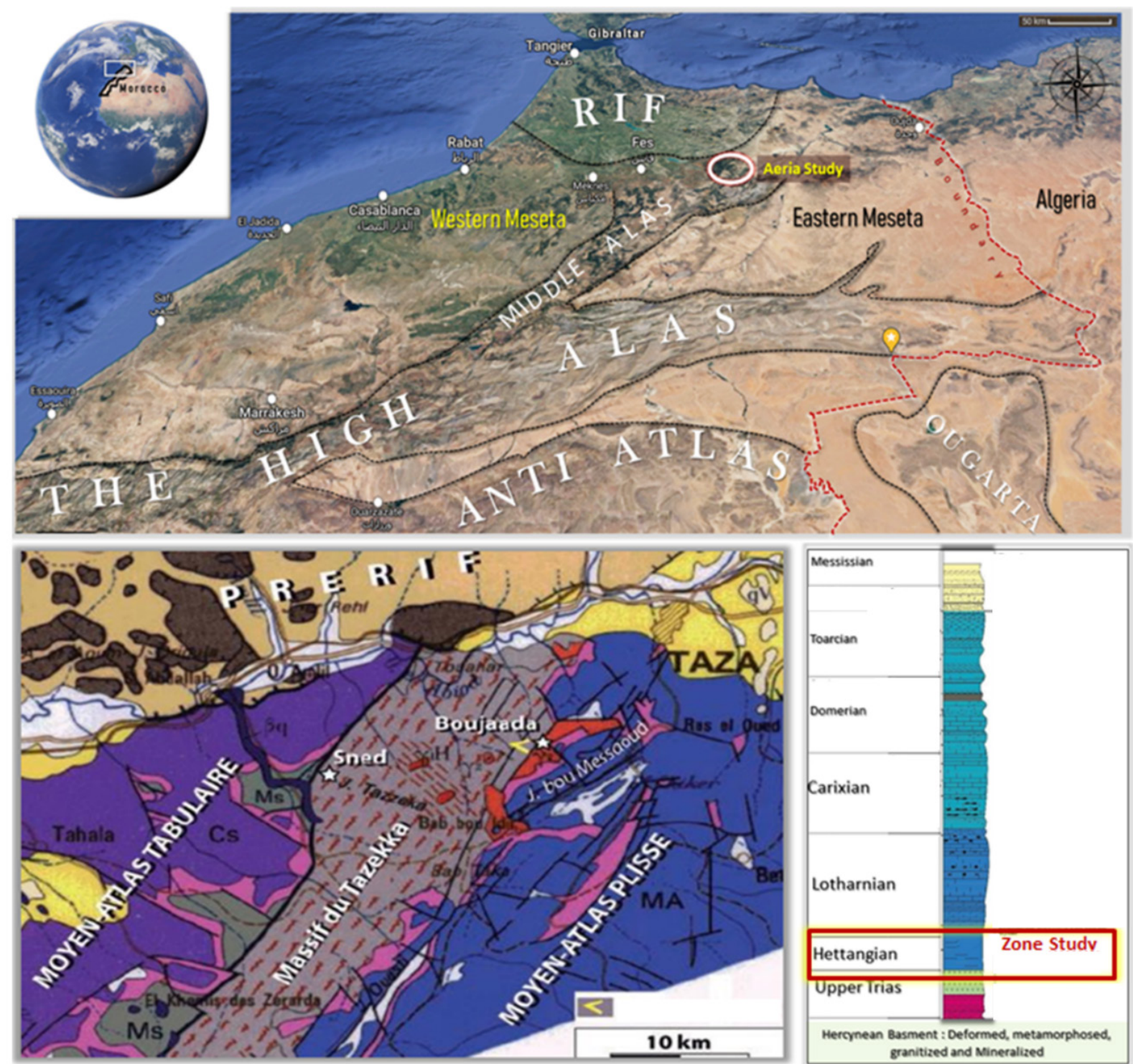

Figure 1. Geographical position of the Zone study situated in the north east of Tazekka, with its geological maps (Geological map of Rif 1/ 500000 , [1]) and stratigraphy 
The Liassic platform of the Tazekka contains some $\mathrm{Pb}-$ $\mathrm{Zn}$ and $\mathrm{Fe}$ deposits, whose distribution is controlled by paleogeography and structure. The mineralization is found along the basin margin and it is related to dolomitization $[10,11]$. It shows a straight paragenesis, essentially based sphalerite and galena, with small amounts of pyrite and chalcopyrite. Sulfides occur in places and commonly form massive aggregates hosted by both hydrothermal dolomite and saddle dolomite $[12,13]$. The deposits are globally stratiform (Ain Hallouf, Ben Zerhla, Ain Tarselt, Ain Khebbab and Bou Khalifa) or open-space filling (Sidi Abdellah), and are located along the borders of grabens formed within the Middle Atlas Causse domain during the major Middle Atlas Toarcian- Bathonian tectonic event $[9,14,15]$. The presence of breccias, layered sediments and fragments confirms the karstic character of the mineralization. In the Lias cover, the mineralization seems to be occurred during two phases: first, the Carixian and so the Toarcian (Auajjar, 1994). Indeed, and based on all these arguments already cited, it appears that the major part of the mineralization detected in the Mesozoic Tazekka cover is stratiform, hosting $\mathrm{Pb}-\mathrm{Zn}$ ores, that take an MVT form $[16,17]$. However, because it is clear that the geological and geodynamical contexts of the area is remarkable in term of mining wealth, we notice that the area is yet unrecognized in terms of mineral exploration and geological prospecting and research.

In this work, we will focus in a first order the lower liasic brecciated dolomitic zones [18] dated hettangian, which may contain some showings of base or precious metal mineralization, and which may give us an idea about the close relation between these mineralization and the buried Hercynian basement, which is granitized, metamorphosed and mineralized ( $\mathrm{Pb}, \mathrm{Zn}, \mathrm{Sb}, \mathrm{Ag}, \mathrm{Au}, \mathrm{Sn}, \mathrm{W}, \mathrm{Fe} . . .$.$) [19].$

\section{Methods \& Characterization}

In this paper, we have based our work on the spatial mapping of hydrothermal alterations in the Maghrawa area via remote sensing [20,21] (Fig. 2). Indeed, it is on the basis of this mapping that we have targeted the potential zones in terms of hydrothermal alteration. We carried out selective sampling of breccea, from which five samples were taken and designed for Geochemical and petrographic analyses.

All the samples were analyzed using inductively coupled plasma analytical techniques for measuring the levels of inorganic elements in the samples (ICP: Inductive Coupled Plasma) $[22,23]$.
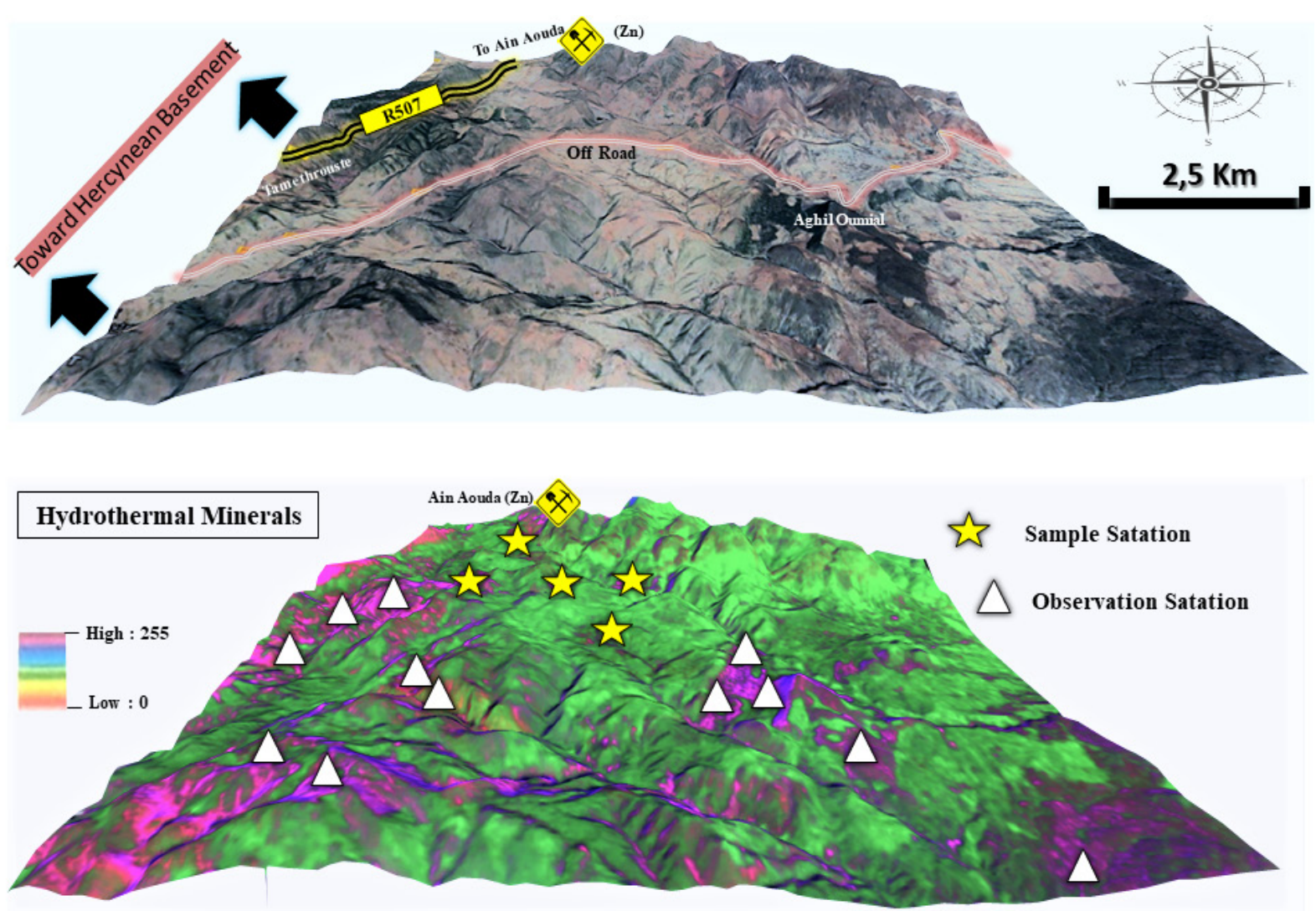

Figure 2. Geographycal position of the study in Maghrawa region, showing the location of the sample stations, and observation stations 
To ensure an optimal characterization, all the samples were analyzed using inductively coupled plasma analytical technics for measuring the levels of inorganic elements in the samples, while XRD (X-Ray Diffraction) [24] patterns were obtained from X'Pert High Score Report using $\mathrm{Cu} \mathrm{K} \alpha$ $(\lambda=1.54178 \AA), 2 \theta$ mode was used to scan all the samples in the range of $30^{\circ} \sim 60^{\circ}$ with the step of $0.02^{\circ}$ and the stay time is $2 \sim 3 \mathrm{~s}$. Finally, to investigate the surface and morphology of the samples, Scanning Electron Microscopy (SEM) analyses were carried out on a FEI Quanta 200 microscope. Each sample is placed on a copper grid covered with a very thin layer of amorphous carbon (20 to $30 \mathrm{~nm}$ of thickness).

Note that all the described studies where carried out in the Innovation City of Science of Fes, University of Sidi Mohammed Ben Abdellah University of Fez - Morocco, while the scientific exchanges and interpretation where in collaboration with ATLAS MINING company; Abdus Salam International; Center of Theoretical Physics (Trieste-Italy) and Africa Graphene Center; Nanosciences African Network, University of South Africa Department of Physics, iThemba Labs (South Africa), African Laser Center.

\section{Results and Discussions}

\subsection{ICP Analysis}

According to the result of the ICP analysis, we note that no occurrence of $(\mathrm{Pb})$ mineralization were detected in all samples, however the $(\mathrm{Zn})(\mathrm{Cu})$ and $(\mathrm{Fe})$ are present as clues of low concentration $(0.018-8 \%)$, except of SS04 which shows a high tenor of $\mathrm{Zn}(36 \%)$ and Iron $(\approx 2 \%)$.

We note that this sample is taken from Ain Aouda region located in the north part of the zone study where an old mine of zinc as kind of strata manifested, and for that reason we conclude and suggest that the existence of high tenors of $(\mathrm{Zn})$ and $(\mathrm{Fe})$ is related to some extension of the principal ore body of Ain Aouda.

For the precious metals, we note the existence considerable $(\mathrm{Ag})$ concentration $(2-4 \mathrm{ppm})$ associated to some gold mineralization (1-7ppm). For the $(\mathrm{Sb})$ we note an average of $282 \mathrm{ppm}$, with $34 \mathrm{ppm}$ of (W) and $164.6 \mathrm{ppm}$ of (Sn).
Based on the geological context/geochemical content, we investigate the crystalline phases and structures of the five samples, by using the techniques of crystallographic analysis by X-ray diffraction.

\subsection{Structural Properties}

\subsubsection{Structural Properties of SS01}

X-ray diffraction (XRD) patterns were used to investigate the phases and structures of our five extracted samples. The XRD pattern of the as-prepared sample SS01 (Fig. 3A) revealed the existence of four phases, calcite, manganocolumbite, tetrahedrite and freibergite.

The diffraction peaks of calcite $\left(\mathrm{CaCO}_{3}\right)$ could be indexed as the trigonal (hexagonal axes) crystalline phase (Space group R-3c), with the lattice constants of $\mathrm{a}=4.9844$ $\AA$ and $\mathrm{c}=17.0376 \AA\left(\alpha=\beta=90^{\circ} \gamma=120^{\circ}\right)$. This is compatible with the standard value of JCPDS: 96-901-6707 already described in the literature [25].

Diffraction peaks of manganocolumbite $\left(\mathrm{Mn}, \mathrm{Fe}^{2+}\right)(\mathrm{Nb}, \mathrm{Ta})_{2} \mathrm{O}_{6}$ can be indexed to the orthorhombic space group Pben with lattice constants of $\mathrm{a}=14.4508 \AA, \mathrm{b}$ $=5.7741 \AA$ and $\mathrm{c}=5.1025 \AA\left(\alpha=\beta=\gamma=90^{\circ}\right)$, in agreement with the standards already described in the literature, i.e. JPCDS 96-901-6707 [26].

Diffraction peaks of tetrahedrite $\left.(\mathrm{Cu}, \mathrm{Fe})_{12} \mathrm{Sb}_{4} \mathrm{~S}_{13}\right)$ can be indexed to the cubic crystalline phase (space group I-4 $3 \mathrm{~m}$ ) were indexed to the space group I-4 $3 \mathrm{~m}$ with calculated lattice constants $\mathrm{a}=\mathrm{b}=\mathrm{c}=10.4033 \AA$ and $\alpha=\beta=\gamma=90^{\circ}$, compatible with the standard already described in the literature, i.e. JCPDS 96-900-3108 [27].

Furthermore, the diffraction peaks of freibergite $(\mathrm{Ag}, \mathrm{Cu}, \mathrm{Fe})_{12}(\mathrm{Sb}, \mathrm{As})_{4} \mathrm{~S}_{13}$ could be indexed to the cubic crystalline phase (space group I $-43 \mathrm{~m}$ ) with the lattice constants $\mathrm{a}=\mathrm{b}=\mathrm{c}=10.4920 \AA$ and $\left(\alpha=\beta=\gamma=90^{\circ}\right)$, compatible with the standard already described in the literature, i.e. JCPDS 96-901-2611 [28]. Note that no peaks of any other phases or impurities were detected in the spectra, which mean that the sample SS01 is mainly composed of calcite, manganocolumbite, tetrahedrite and freibergite. The diagram in (Fig. 3B) present an estimation of mineral percentage's calculated using the crystal impact software "Match Phase Analysis" which indicates respectively $44,1 \%$ of calcite, $27,7 \%$ of manganocolumbite, $14,2 \%$ of tetrahedrite and $14 \%$ of freibergite.

Table 1. Results of ICP analysis

\begin{tabular}{|c|c|c|c|c|c|c|c|c|c|}
\hline & $\mathrm{Pb}(\%)$ & $\mathrm{Zn}(\%)$ & $\mathrm{Cu}(\%)$ & $\mathrm{Fe}(\%)$ & $\mathrm{Ag}(\mathrm{ppm})$ & $\mathrm{Au}(\mathrm{ppm})$ & $\mathrm{Sn}(\mathrm{ppm})$ & $\mathrm{W}(\mathrm{ppm})$ & $\mathrm{Sb}(\mathrm{ppm})$ \\
\hline SS01 & LD & 0.032 & 2 & 0.7 & 2 & 7 & 34 & 30 & 236 \\
\hline SS02 & LD & 0.018 & 8 & 0.62 & 4 & 3 & 156 & 89 & 384 \\
\hline SS03 & LD & 0.3 & 5 & 2 & 3 & 5 & 412 & 20 & 573 \\
\hline SS04 & LD & 36 & LD & 1.9 & 2 & 1 & 11 & 22 & 99 \\
\hline SS05 & LD & 0.3 & LD & 1 & 3 & 4 & 210 & 9 & 120 \\
\hline
\end{tabular}




\subsubsection{Structural Properties of SS02}

The XRD pattern of the as-prepared sample SS02 (Fig. 4A) revealed the existence of five phases, calcite, freibergite, sylvanite, antimony iodide, and stistaite. The diffraction peaks of calcite $\left(\mathrm{CaCO}_{3}\right)$ can be indexed as the trigonal (hexagonal axes) crystalline phase (space group $\mathrm{R}-3 \mathrm{c}$ ), with the lattice constants of $\mathrm{a}=4.9766 \AA$ and $\mathrm{c}=$ $17.2840 \AA\left(\alpha=\beta=90^{\circ} \gamma=120^{\circ}\right)$ compatible with the standard already described in the literature, i.e. JCPDS: 96-901-5482 [29].

In the case of freibergite $(\mathrm{Ag}, \mathrm{Cu}, \mathrm{Fe})_{12}(\mathrm{Sb}, \mathrm{As})_{4} \mathrm{~S}_{13}$, the diffraction peaks can be indexed to the cubic crystalline phase (space group I $-43 \mathrm{~m}$ ) with lattice constants $\mathrm{a}=\mathrm{b}=\mathrm{c}$ $=10.6100 \AA$ and $\left(\alpha=\beta=\gamma=90^{\circ}\right)$, compatible with the standard described in the literature, i.e. JCPDS: 96-900-9469 already [30].

The diffraction peaks of sylvanite $(\mathrm{Au}, \mathrm{Ag})_{2} \mathrm{Te}_{4}$ can be readily indexed to the monoclinic crystalline phase (space group P 12/c1) with calculated lattice constants $a=8.9600$ $\AA, \mathrm{b}=4.4900 \AA$ and $\mathrm{c}=14.6200 \AA$ and $\left(\beta=145.430^{\circ}\right)$, compatible with the standard described in the literature, i.e.
JCPDS: 96-231-0990 already [31].

Furthermore, the diffraction peaks of native antimony iodide $\left(\mathrm{SbI}_{3}\right)$ could be readily indexed to the trigonal (hexagonal axes) crystalline phase (space group R-3m) with the lattice constants $\mathrm{a}=4.2687 \AA$ and $\mathrm{c}=10.9244 \AA$ $\left(\alpha=\beta=90^{\circ} \gamma=120^{\circ}\right)$, compatible with the standard described in the literature, i.e. JCPDS 96-810-0524 already [32].

Finally, the diffraction peaks of stistaite ( $\mathrm{SbSn})$ can be indexed as the rhombohedral crystalline phase (space group R-3m) with lattice constants of $\mathrm{a}=6.1240 \AA$ and $\alpha=$ $89.380^{\circ}$ compatible with the standard already described in the literature, i.e. JCPDS: 96-901-3159 [33]. Mark that no peaks of any other phases or impurities were detected in the spectra, which means that the sample SS02 is mostly composed of calcite, freibergite, sylvanite, antimony and stistaite. The diagram in (Fig. 4B) presents an estimation of these element's percentages, where the software calculations (Match phase analysis) describe $50,8 \%$ of calcite, $16.5 \%$ of sylvanite, $13,4 \%$ of antimony and $8.9 \%$ of stistaite.
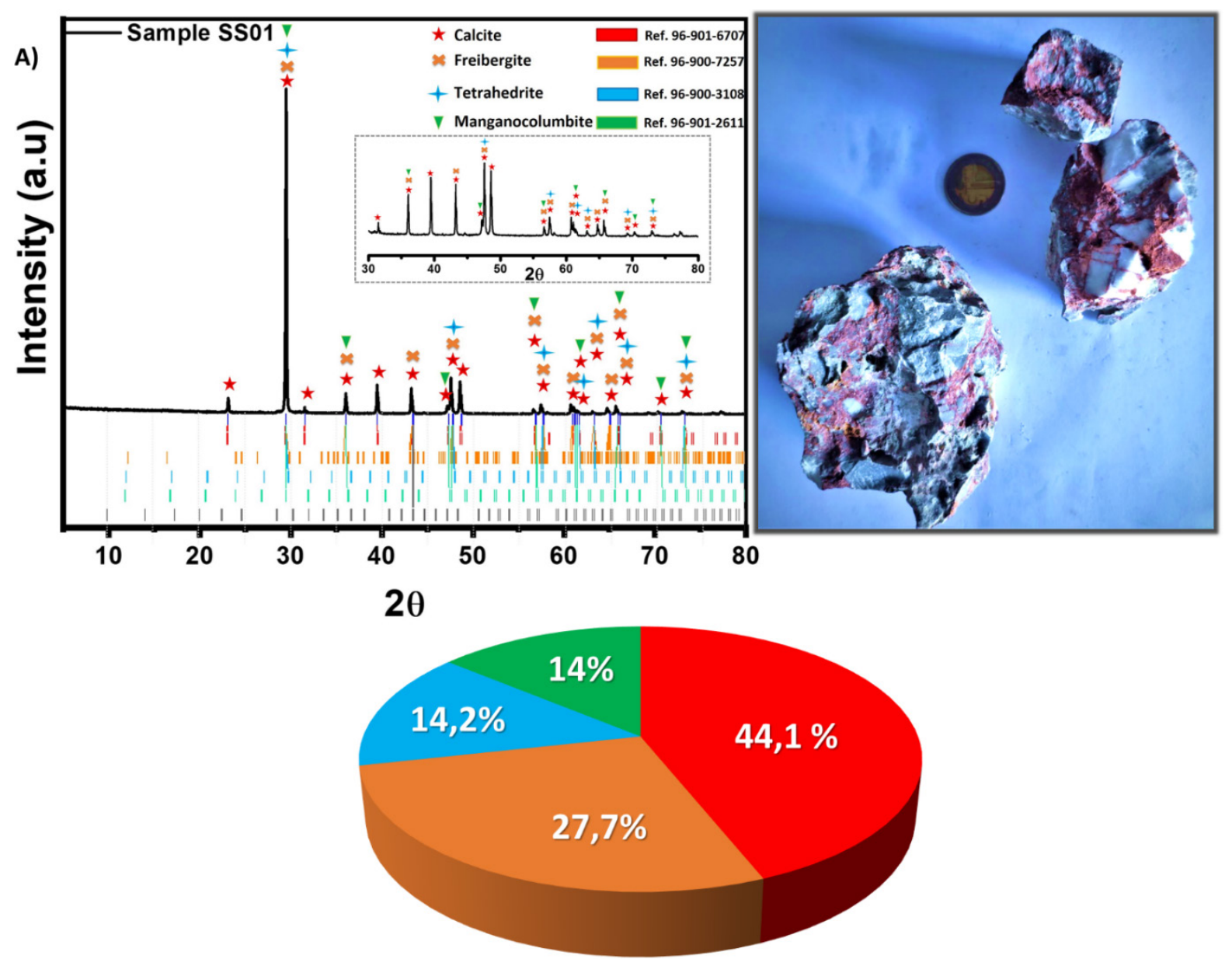

Figure 3. (A) X-rays diffraction (XRD) patterns of sample SS01 and (B) phase percentage of calcite, manganocolumbite, tetrahedrite and freibergite 

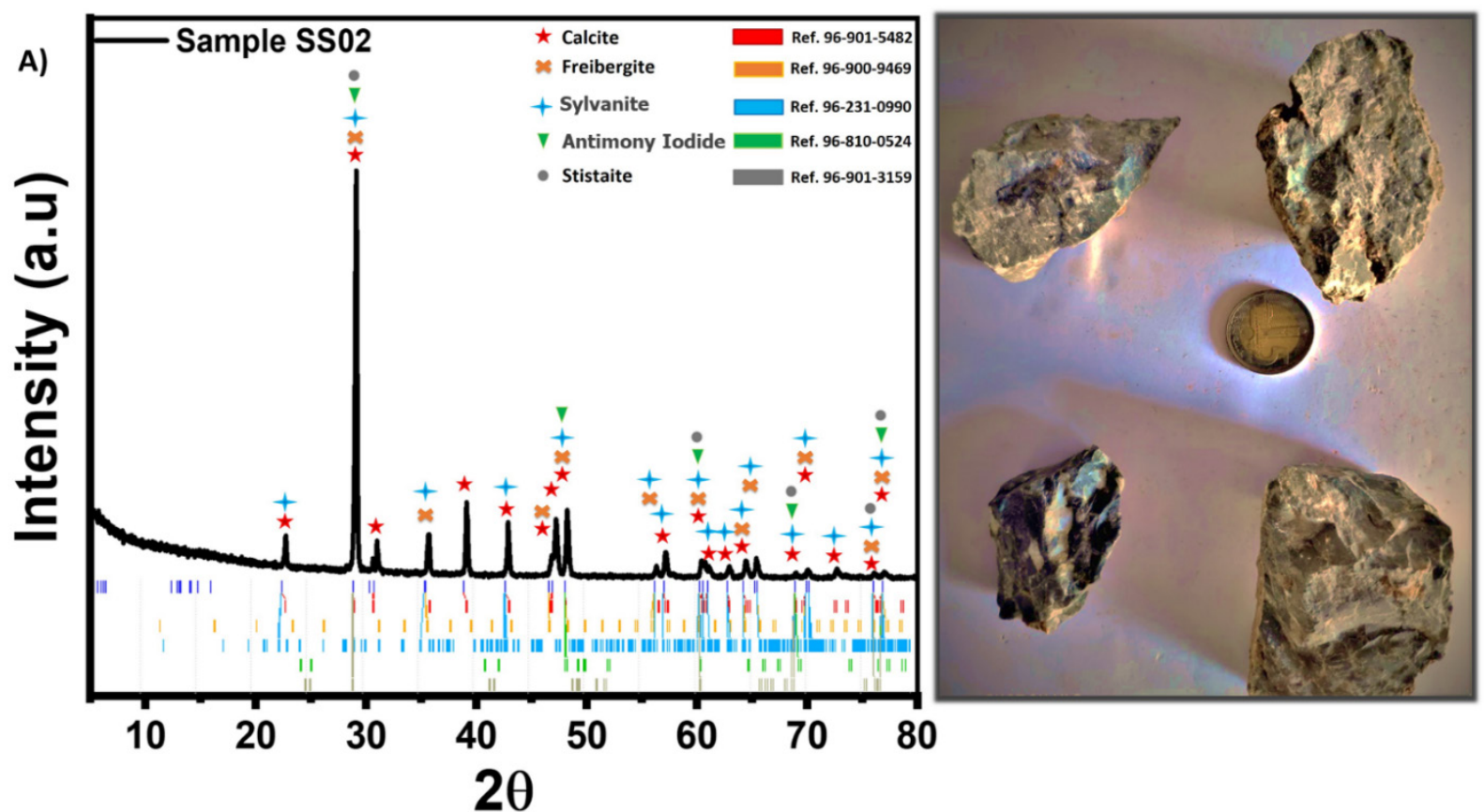

B)

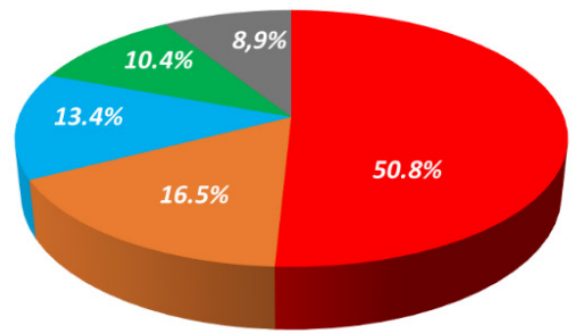

Figure 4. (A) X-rays diffraction (XRD) patterns of sample SS02 and (B) Phases percentage of calcite, freibergite, sylvanite, antimony iodide and stistaite

\subsubsection{Structural properties of $\mathrm{SS} 03$}

The XRD pattern of the as-prepared sample SS03 (Fig. $5 \mathrm{~A})$ revealed the existence of six phases, calcite, tin (II) halide sulphates, barium iron Selenide, freibergite, tetrahedrite and zinc germanium \pm barite. The diffraction peaks of calcite $\left(\mathrm{CaCO}_{3}\right)$ can be indexed as the trigonal (hexagonal axes) crystalline phase (space group R-3c) with the lattice constants $\mathrm{a}=4.9860 \AA$ and $\mathrm{c}=17.0592 \AA(\alpha=\beta$ $=90^{\circ} \gamma=120^{\circ}$ ), compatible with the standard described in the literature, i.e. JCPDS: 96-154-7350 already [34].

Diffraction peaks of tin (II) halide sulphates $\left(\mathrm{K}_{3} \mathrm{Sn}_{2}\left(\mathrm{SO}_{4}\right)_{3} \mathrm{Cl}\right)$ can be indexed to the hexagonal crystalline phase (space group P 63) with lattice constants a $=10.1830$ and $\mathrm{c}=7.5400 \AA$ and $\left(\alpha=\beta=90^{\circ}\right.$ and $\left.\gamma=120^{\circ}\right)$, compatible with the standard already described in the literature, i.e. JCPDS: 96-403-1435 [35]. The diffraction peaks of barium iron selenide $\left(\mathrm{BaFe}_{2} \mathrm{Se}_{3}\right)$ can be readily indexed to the orthorhombic crystalline phase (space group $\mathrm{P}$ nma) with calculated lattice constants $\mathrm{a}=11.9996 \AA \mathrm{A}, \mathrm{b}=$ $5.4711 \AA$ and $\mathrm{c}=9.2156 \AA$ and $\left(\alpha=\beta=\gamma=90^{\circ}\right)$, compatible with the standard already described in the literature, i.e. JCPDS: 96-150-4314 [36].

Furthermore, the diffraction peaks of freibergite $(\mathrm{Ag}, \mathrm{Cu}, \mathrm{Fe})_{12}(\mathrm{Sb}, \mathrm{As})_{4} \mathrm{~S}_{13}$ could be readily indexed to the cubic crystalline phase (space group I-43m) with lattice constants $\mathrm{a}=\mathrm{b}=\mathrm{c}=10.4920 \AA\left(\alpha=\beta=\gamma=90^{\circ}\right)$, compatible with the standard described in the literature, i.e. JCPDS 96-901-2611 already [28].

Diffraction peaks of tetrahedrite $\left.\left(\mathrm{Cu}, \mathrm{Fe}_{12}\right)_{12} \mathrm{Sb}_{4} \mathrm{~S}_{13}\right)$ could be readily indexed to the cubic crystalline phase (space group I-43m) with lattice constants $\mathrm{a}=\mathrm{b}=\mathrm{c}=10.5030 \AA$ $\left(\alpha=\beta=\gamma=90^{\circ}\right)$, compatible with the standard already described in the literature, i.e. JCPDS 96-150-9592 [37].

Finally, the diffraction peaks of zinc germanium \pm barite (Ba, Ge,Sn) can be indexed as hexagonal crystalline phase (Space group P 63/mmc), with lattice constants a $=4.4570$ $\AA$ and $\mathrm{c}=9.65500 \AA$ and $\left(\alpha=\beta=90^{\circ}\right.$ and $\left.\gamma=120^{\circ}\right)$, compatible with the standard described in the literature, i.e. JCPDS: 96-152-7802 already [39].

Hence, no peaks of any other phases or impurities were detected in the spectra, which mean that the sample $\mathrm{SSO} 03$ is composed of calcite, tin (II) halide sulphates, barium iron selenide, tetrahedrite and zinc germanium \pm barite. The diagram in (Fig. 5B) presents an estimation of these element's percentage calculated using the software Match Phase Analysis, where the obtained percentage was found to be respectively $(65.4 \%),(14.9 \%),(6.2 \%),(5.1 \%),(5 \%)$ and $(3.3 \%)$. 

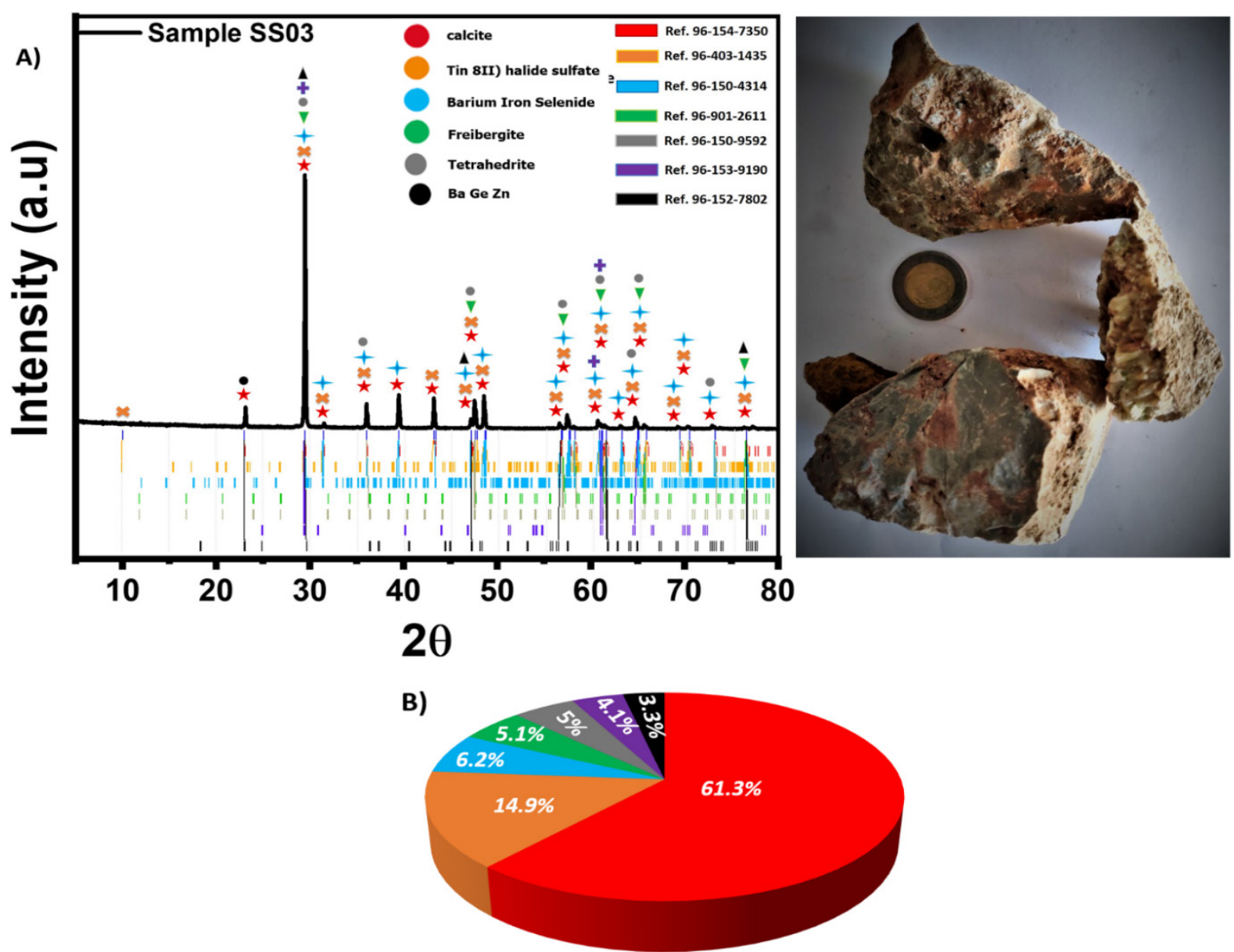

Figure 5. (A) X-rays diffraction (XRD) patterns of sample SS03 and (B) Phases percentage of calcite, tin (II) halide sulphate, barium iron selenide, freibergite, tetrahedrite, barium zinc germanium.

\subsubsection{Structural Properties of SS04}

The XRD pattern of the as-prepared sample SS04 (Fig. 6A) revealed the existence of five phases, calcite, chalcopyrite, krennerite, zinc telluride, antimony iodide and stistaite. The diffraction peaks of calcite $\left(\mathrm{CaCO}_{3}\right)$ could be indexed as the trigonal (hexagonal axes) crystalline phase (space group R-3c) with lattice constants $\mathrm{a}=4.9844 \AA$ and $\mathrm{c}=17.0376 \AA\left(\alpha=\beta=90^{\circ} \gamma=120^{\circ}\right)$, compatible with the standard described in the literature, i.e. JCPDS: 96-901-6707 already [40].

In the case of copper iron sulphide, the diffraction peaks of chalcopyrite $\left(\mathrm{CuFeS}_{2}\right)$ can be indexed to the tetragonal crystalline phase (space group $\mathrm{P}-42 \mathrm{~m}$ ) with lattice constants $\mathrm{a}=5.2700 \AA$ and $\mathrm{c}=5.1940 \AA\left(\alpha=\beta=\gamma=90^{\circ}\right)$, compatible with the standard outlined in the literature, i.e. JCPDS: 96-101-0319 already [41].

Indeed, the diffraction peaks of krennerite $\left(\mathrm{AuTe}_{2}\right)$ can be catalogued to the orthorhombic crystalline phase (space group $\mathrm{P}$ ma2) with calculated lattice constants $\mathrm{a}=16.5800$ $\AA, \mathrm{b}=8.8490 \AA$ and $\mathrm{c}=4.4640 \AA$ and $\left(\left(\alpha=\beta=\gamma=90^{\circ}\right)\right.$, accordant with the standard described in the literature, i.e. JCPDS: 96-900-9619 already [42].

Furthermore, the diffraction peaks of zinc telluride $(\mathrm{Zn}, \mathrm{Te})$ can be readily indexed to the cubic crystalline phase (space group $\mathrm{F} \mathrm{m}-3 \mathrm{~m}$ ) with lattice constants $\mathrm{a}=\mathrm{b}=\mathrm{c}$ $=6.0700 \AA\left(\alpha=\beta=\gamma=90^{\circ}\right)$, compatible with the standard already described in the literature, i.e. JCPDS 96-101-0536 [43].

Diffraction peaks of antimony Iodide $\left(\mathrm{SbI}_{3}\right)$ can be indexed as the trigonal (hexagonal axes) crystalline phase (space group R-3m), with lattice constants a $=4.2687 \AA$ and $\mathrm{c}=10.9244 \AA\left(\alpha=\beta=90^{\circ} \gamma=120^{\circ}\right)$, compatible with the standard already described in the literature, i.e. JCPDS: 96-810-0524 [32].

Finally, the diffraction peaks of the stistaite $(\mathrm{SbSn})$, could be indexed as the rhombohedral crystalline phase (space group R-3m), with lattice constants $\mathrm{a}=6.1240 \AA$ and $\left(\alpha=89.380^{\circ}\right)$, compatible with the standard assigned in the literature, i.e. JCPDS: 96-901-3159 already [33].

Note that no peaks of any other phases or impurities were detected in the spectra, which mean that the sample SS03 is mainly composed of calcite, copper iron sulphide, krennerite, zinc telluride, antimony and stistaite. The diagram in (Fig. 6B) shows an estimation of these element's percentage calculated using the software Match Phase Analysis, where the obtained percentage was found to be respectively $(46.2 \%),(16.3 \%),(10.9 \%),(9.6 \%)$, $(9.2 \%)$ and $(7.9 \%)$. 

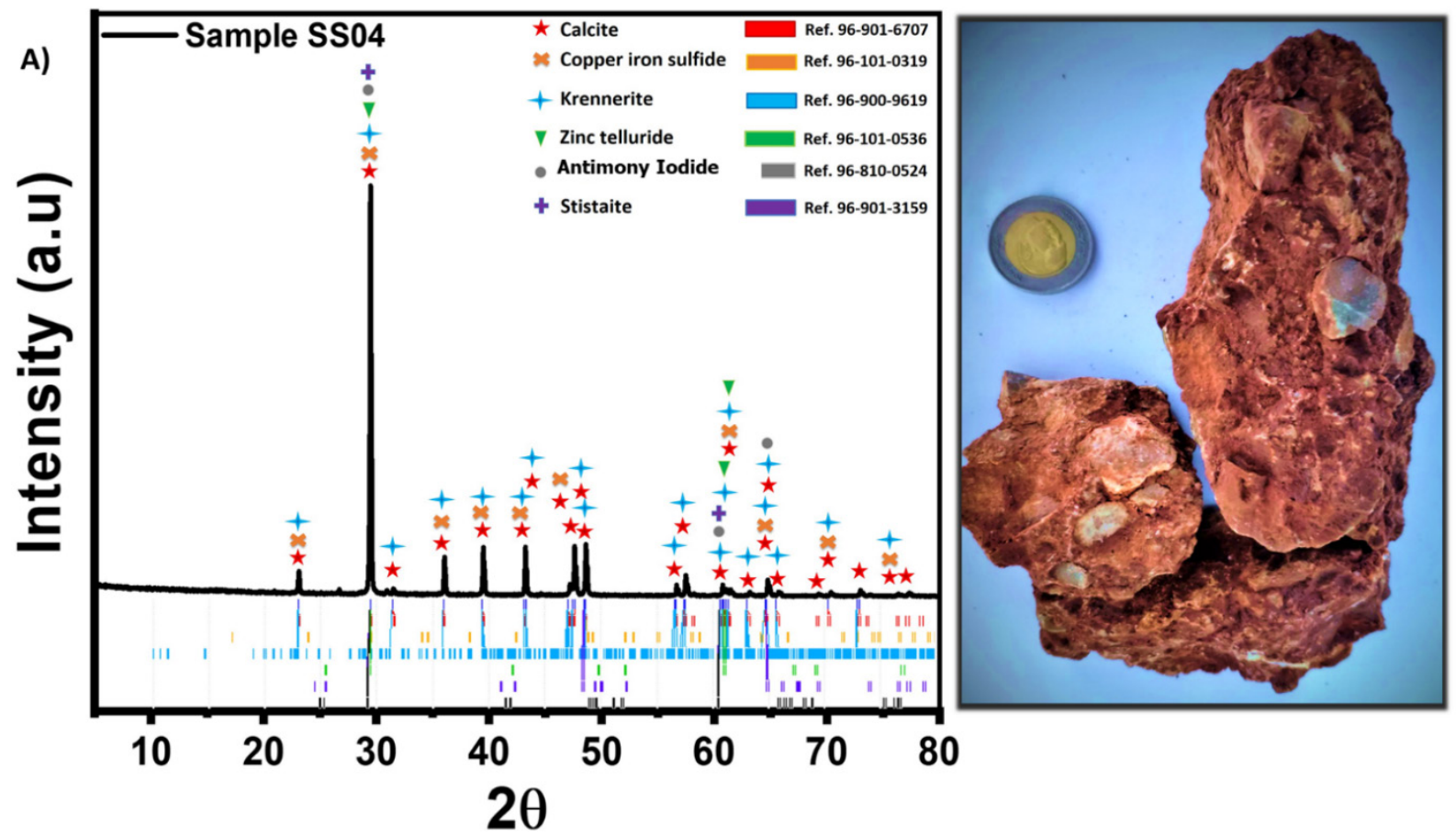

B)

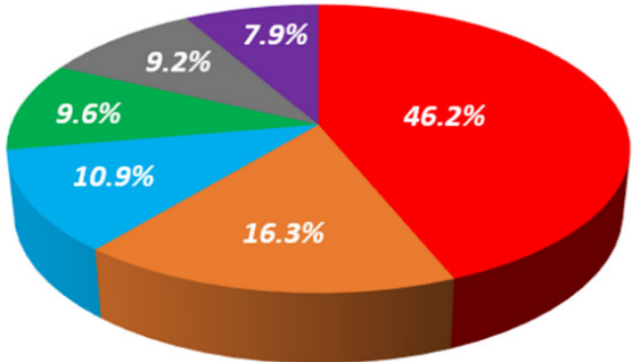

Figure 6. (A) X-rays diffraction (XRD) patterns of sample SS04 and (B) Phases percentage of calcite, copper iron sulphide, krennerite, zinc telluride, antimony iodide and stistaite

\subsubsection{Structural Properties of SS05}

Theoparacelsite, iron (II) iodide, niobium sulphate, calcite, silver telluride, germanium antimony telluride, dicesium potassium manganese and sodium nitrate. The diffraction peaks of theoparacelsite $(\mathrm{Cu} 3(\mathrm{OH}) 2(\mathrm{As} 2 \mathrm{O} 7)$ could be indexed as the orthorhombic crystalline phase (Space group P mma) with calculated lattice constants $\mathrm{a}=$ $8.3212 \AA, b=2.9377 \AA$ and $c=4.6644 \AA$ and $(\alpha=\beta=\gamma=$ $90^{\circ}$ ), compatible with the standard described in the literature, i.e. of JCPDS: 96-900-9987 already [44].

The diffraction peaks of iron (II) iodide $\left(\mathrm{FeI}_{2}\right)$ could be indexed as the trigonal (hexagonal axes) crystalline phase (space group P-3m1), with lattice constants a $=4.0400 \AA$ and $\mathrm{c}=6.7500 \AA\left(\alpha=\beta=90^{\circ} \gamma=120^{\circ}\right)$, compatible with the standard noticed in the literature, i.e. JCPDS: 96-900-9104 already [46]. Moreover, the diffraction peaks of niobium sulphate $\left(\mathrm{NbO}_{4} \mathrm{~S}\right)$ can be readily indexed to the orthorhombic crystalline phase (space group $\mathrm{P}$ na21) with calculated lattice constants $\mathrm{a}=5.5140 \AA, \mathrm{b}=4.8761 \AA$ and $c=11.7961 \AA$ and $\left(\alpha=\beta=\gamma=90^{\circ}\right)$ corresponding to the standard described in the literature, i.e. JCPDS: 96-152-6181 already [45].

For the calcite $\left(\mathrm{CaCO}_{3}\right)$, the diffraction peaks can be indexed as the trigonal (hexagonal axes) crystalline phase (space group R-3c) with lattice constants $\mathrm{a}=4.9761 \AA$ and $c=17.4163 \AA\left(\alpha=\beta=90^{\circ} \gamma=120^{\circ}\right)$, compatible with the standard value of JCPDS: 96-901-4345 already described in the literature [29]. 

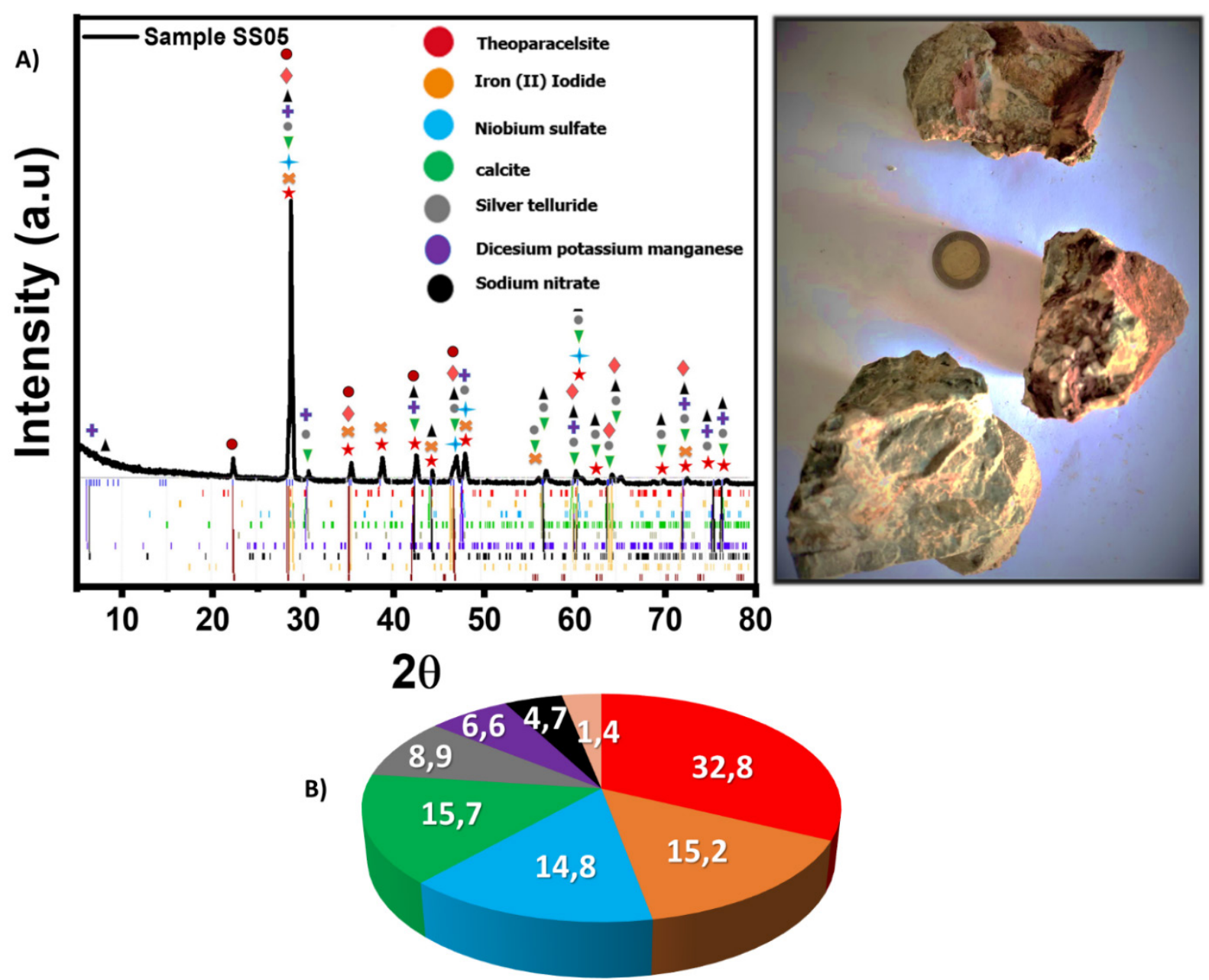

Figure 7. (A) X-rays diffraction (XRD) patterns of sample SS05 and (B) Phases percentage of t1qheoparacelsite, iron (II) iodide, niobium sulphate, calcite, silver telluride, dicesium potassium manganese, sodium nitrate

In the case of silver Telluride $\left(\mathrm{Ag}_{2} \mathrm{Te}\right)$, the diffraction peaks can be indexed as the trigonal (hexagonal axes) crystalline phase (space group P-3m1) with lattice constants $\mathrm{a}=4.2820 \AA$ and $\mathrm{c}=28.6360 \AA\left(\alpha=\beta=90^{\circ} \gamma=\right.$ $\left.120^{\circ}\right)$, compatible with the standard value of JCPDS: 96-700-0756 already described in the literature [46].

Furthermore, the diffraction peaks of germanium antimony telluride $\left(\mathrm{Ge}_{2} \mathrm{Sb}_{2} \mathrm{Te}_{3}\right)$ could be indexed as the trigonal (hexagonal axes) crystalline phase (space group $\mathrm{R}-3 \mathrm{~m})$ with lattice constants $\mathrm{a}=4.2495 \AA$ and $\mathrm{c}=41.2990$ $\AA\left(\alpha=\beta=90^{\circ} \gamma=120^{\circ}\right)$, compatible with the standard described in the literature, i.e. JCPDS: 96-703-1376 already [47].

In addition, the diffraction peaks of dicesium potassium manganese $\left(\mathrm{Cs}_{2} \mathrm{~F}_{6} \mathrm{KMn}\right)$ can be readily indexed to the tetragonal crystalline phase (Space group I $4 / \mathrm{mmm}$ ) with lattice constants $\mathrm{a}=6.1260 \AA$ and $\mathrm{c}=8.9810 \AA(\alpha=\beta=\gamma=$ $90^{\circ}$ ), this is compatible with the standard value of JCPDS: 96-152-2261 already described in the literature [48].

Finally, the diffraction peaks of sodium nitrate $\left(\mathrm{Na}\left(\mathrm{NO}_{3}\right)\right.$, can be indexed as the trigonal (hexagonal axes) crystalline phase (Space group R-3m) with the lattice constants $\mathrm{a}=$ $5.0889 \AA$ and $\mathrm{c}=8.8680 \AA\left(\alpha=\beta=90^{\circ} \gamma=120^{\circ}\right)$, compatible with the standard already described in the literature, i.e. JCPDS: 96-810-3617 [49].

Hence, no peaks of any other phases or impurities were detected in the spectra, which mean that the sample SS05 is mainly composed of Calcite, Iron (II) Iodide, Niobium Sulphate, Theoparacelsite, Silver antimony telluride, Germanium Antimony Telluride, Dicesium Potassium Manganese and Sodium Nitrate.

The diagram in (Fig. 7B) presents an estimation of these element's percentage calculated using the software Match Phase Analysis where the obtained percentage was found to be respectively $(32.8 \%),(15.2 \%),(14.8 \%),(12.5 \%)$, (8.9\%), (6.6\%), (4.7\%), (3.2\%), and (1.4\%).

\subsubsection{Structural Interpretation}

Note that the average crystallite size of the five extracted samples was calculated by using Scherrer's formula [50]:

$$
\mathbf{d}=\mathbf{K \lambda} / \boldsymbol{\beta} \cos (\boldsymbol{\theta})
$$

Where (d) is the average crystallite size, $\mathrm{K}$ is a dimensionless shape factor, with a value close to unity, called the Scherrer constant. The shape factor has a typical value of about 0.89 , but varies with the actual shape of the 
crystallite, $\lambda$ is the wavelength of $\mathrm{X}$-ray source used in $\operatorname{XRD}(\lambda=0.15418 \mathrm{~nm}), \beta$ is the full width at half the maximum intensity (FWHM) and $\theta$ is the diffraction angle in degrees.

The average crystallite size values calculated from XRD (using the most intense peak) patterns of SS01, SS02, $\mathrm{SS} 03$, SS04 and SS05 have been found to be 72.55, 65.53, 52.41, 38.62 and $78.63 \mathrm{~nm}$ respectively (Fig. 8).
In addition, the typical panoramic SEM images presented in (Fig. 8) Obviously shows smaller microparticles in all samples with a non-uniform size distribution confirming the existence of numerous phases in each sample. Furthermore, the overall products, compositions, crystalline phases, space groups, lattice parameters, densities and cristalite sizes are summarized in the Table 2.

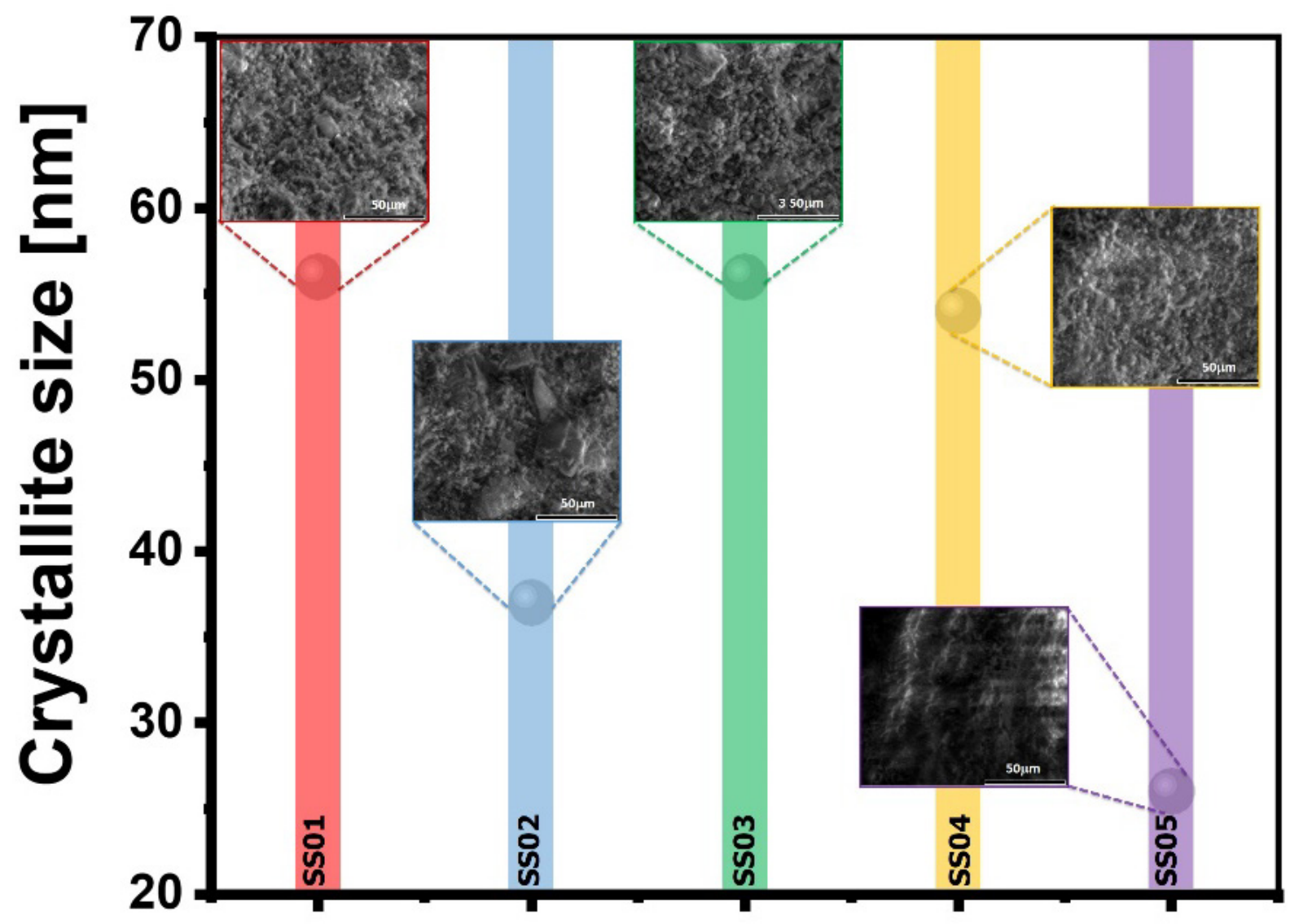

Figure 8. The crystallite size of our four samples calculated by using Scherrer's formula 
Table 2. Compositions, crystalline phases, space groups, lattice parameters, densities and crystalline sizes of our five extracted samples

\begin{tabular}{|c|c|c|c|c|c|c|c|c|}
\hline \multicolumn{9}{|c|}{ SS01 } \\
\hline \multirow{2}{*}{ Product } & \multirow{2}{*}{$(\%)$} & \multirow{2}{*}{ Crystalline phase } & \multirow{2}{*}{$\begin{array}{l}\text { Space } \\
\text { group }\end{array}$} & \multicolumn{2}{|c|}{ Mesh Parameters } & \multirow[t]{2}{*}{ Density $\left(\mathrm{g} / \mathrm{cm}^{3}\right)$} & \multirow{2}{*}{ Size [51] } & \multirow{2}{*}{ Ref } \\
\hline & & & & Lattice parameter $(\AA)$ & Angles & & & \\
\hline calcite & 44.1 & Trigonal (hexagonal axes) & $\mathrm{R}-3 \mathrm{c}$ & $\mathrm{a}=\mathrm{b}=4.98, \mathrm{c}=17.03$ & $\alpha=\beta=90^{\circ}, \gamma=120^{\circ}$ & 2.720 & \multirow{4}{*}{$56 \mathrm{~nm}$} & {$[25]$} \\
\hline manganocolumbite & 27.7 & Orthorhombic & Pben & $\mathrm{a}=14.45, \mathrm{~b}=5.77, \mathrm{c}=5.10$ & $\alpha=\beta=\gamma=90^{\circ}$ & 5.438 & & {$[26]$} \\
\hline tetrahedrite & 14.2 & Cubic & $\mathrm{I}-43 \mathrm{~m}$ & $\mathrm{a}=\mathrm{b}=\mathrm{c}=10.40$ & $\alpha=\beta=\gamma=90^{\circ}$ & 5.235 & & {$[27]$} \\
\hline freibergite & 14 & Cubic & $\mathrm{I}-43 \mathrm{~m}$ & $\mathrm{a}=\mathrm{b}=\mathrm{c}=10.49$ & $\alpha=\beta=\gamma=90^{\circ}$ & 5.442 & & {$[28]$} \\
\hline \multicolumn{8}{|c|}{$\mathrm{SS} 02$} & \\
\hline calcite & 50.8 & Trigonal (hexagonal axes) & $\mathrm{R}-3 \mathrm{c}$ & $\mathrm{a}=\mathrm{b}=4.97, \mathrm{c}=17.28$ & $\alpha=\beta=90^{\circ}, \gamma=120^{\circ}$ & 2.690 & \multirow{5}{*}{$37 \mathrm{~nm}$} & {$[29]$} \\
\hline freibergite & 16.5 & Cubic & $\mathrm{I}-43 \mathrm{~m}$ & $\mathrm{a}=\mathrm{b}=\mathrm{c}=10.61$ & $\alpha=\beta=\gamma=90^{\circ}$ & 5.104 & & {$[30]$} \\
\hline sylvanite & 14.3 & Monoclinic & $\mathrm{P} 12 / \mathrm{c} 1$ & $\mathrm{a}=8.96, \mathrm{~b}=4.49, \mathrm{c}=14.62$ & $\beta=145.43^{\circ}$ & 8.112 & & {$[31]$} \\
\hline Antimony iodide & 10.4 & Trigonal (hexagonal axes) & $\mathrm{R}-3 \mathrm{~m}$ & $\mathrm{a}=\mathrm{b}=4.26, \mathrm{c}=10.92$ & $\alpha=\beta=90^{\circ}, \gamma=120^{\circ}$ & 7.035 & & {$[32]$} \\
\hline stistaite & 8.9 & Rhombohedral & $\mathrm{R}-3 \mathrm{~m}$ & $a=6.12$ & $\alpha=89.380^{\circ}$ & 6.955 & & {$[33]$} \\
\hline \multicolumn{8}{|c|}{$\mathrm{SS} 03$} & \\
\hline calcite & 61.3 & Trigonal (hexagonal axes) & $\mathrm{R}-3 \mathrm{c}$ & $\mathrm{a}=\mathrm{b}=4.98, \mathrm{c}=17.05$ & $\alpha=\beta=90^{\circ}, \gamma=120^{\circ}$ & 11.079 & \multirow{6}{*}{$56 \mathrm{~nm}$} & {$[34]$} \\
\hline tin (II) halide sulphates & 14.9 & Hexagonal & P 63 & $\mathrm{a}=\mathrm{b}=10.18, \mathrm{c}=7.54$ & $\alpha=\beta=90^{\circ}, \gamma=120^{\circ}$ & 3.331 & & {$[35]$} \\
\hline barium Iron Selenide & 6.2 & Orthorhombic & $\mathrm{P}$ nma & $\mathrm{a}=11.99, \mathrm{~b}=5.47, \mathrm{c}=9.21$ & $\alpha=\beta=\gamma=90^{\circ}$ & 5.335 & & {$[36]$} \\
\hline freibergite & 5.1 & Cubic & $\mathrm{I}-43 \mathrm{~m}$ & $\mathrm{a}=\mathrm{b}=\mathrm{c}=10.49$ & $\alpha=\beta=\gamma=90^{\circ}$ & 5.442 & & {$[28]$} \\
\hline tetrahedrite & 5.0 & Cubic & $\mathrm{I}-43 \mathrm{~m}$ & $\mathrm{a}=\mathrm{b}=\mathrm{c}=10.50$ & $\alpha=\beta=\gamma=90^{\circ}$ & 4.959 & & [37] \\
\hline barium zinc germanium & 3.3 & Hexagonal & $\mathrm{P} 63 / \mathrm{mmc}$ & $\mathrm{a}=\mathrm{b}=4.45, \mathrm{c}=9.65$ & $\alpha=\beta=90^{\circ}, \gamma=120^{\circ}$ & 5.505 & & [39] \\
\hline \multicolumn{9}{|c|}{ SS04 } \\
\hline calcite & 46.2 & Trigonal (hexagonal axes) & $\mathrm{R}-3 \mathrm{c}$ & $\mathrm{a}=\mathrm{b}=4.98, \mathrm{c}=17.03$ & $\alpha=\beta=90^{\circ}, \gamma=120^{\circ}$ & 2.720 & \multirow{6}{*}{$54 \mathrm{~nm}$} & [47] \\
\hline chalcopyrite & 16.3 & Tetragonal & P-42m & $\mathrm{a}=\mathrm{b}=5.27, \mathrm{c}=5.19$ & $\alpha=\beta=\gamma=90^{\circ}$ & 4.225 & & {$[40]$} \\
\hline krennerite & 10.9 & Orthorhombic & P ma2 & $\mathrm{a}=16.58, \mathrm{~b}=8.84, \mathrm{c}=4.46$ & $\alpha=\beta=\gamma=90^{\circ}$ & 8.833 & & [41] \\
\hline zinc telluride & 9.6 & Cubic & $\mathrm{F} \mathrm{m}-3 \mathrm{~m}$ & $\mathrm{a}=\mathrm{b}=\mathrm{c}=6.07$ & $\alpha=\beta=\gamma=90^{\circ}$ & 5.731 & & [42] \\
\hline antimony & 9.2 & Trigonal (hexagonal axes) & $\mathrm{R}-3 \mathrm{~m}$ & $\mathrm{a}=\mathrm{b}=4.26, \mathrm{c}=10.92$ & $\alpha=\beta=90^{\circ}, \gamma=120^{\circ}$ & 7.035 & & [32] \\
\hline stistaite & 7.9 & Rhombohedral & $\mathrm{R}-3 \mathrm{~m}$ & $a=6.12$ & $\alpha=89.380^{\circ}$ & 6.955 & & [33] \\
\hline \multicolumn{9}{|c|}{ SS05 } \\
\hline Theoparacelsite & 32.8 & Orthorhombic & P mma & $\mathrm{a}=8.32, \mathrm{~b}=2.93, \mathrm{c}=4.66$ & $\alpha=\beta=\gamma=90^{\circ}$ & 4.703 & \multirow{8}{*}{$26 \mathrm{~nm}$} & [43] \\
\hline Iron (II) Iodide & 14.8 & Trigonal (hexagonal axes) & $\mathrm{P}-3 \mathrm{~m} 1$ & $\mathrm{a}=\mathrm{b}=4.04, \mathrm{c}=6.75$ & $\alpha=\beta=90^{\circ}, \gamma=120^{\circ}$ & 5.389 & & [44] \\
\hline Niobium Sulfate & 12.5 & Orthorhombic & P na21 & $\mathrm{a}=5.51, \mathrm{~b}=4.87, \mathrm{c}=11.79$ & $\alpha=\beta=\gamma=90^{\circ}$ & 6.137 & & [46] \\
\hline Calcite & 8.9 & Trigonal (hexagonal axes) & $\mathrm{R}-3 \mathrm{c}$ & $\mathrm{a}=\mathrm{b}=4.97, \mathrm{c}=17.41$ & $\alpha=\beta=90^{\circ}, \gamma=120^{\circ}$ & 2.670 & & [29] \\
\hline Silver telluride & 6.6 & Trigonal (hexagonal axes) & $\mathrm{P}-3 \mathrm{~m} 1$ & $\mathrm{a}=\mathrm{b}=4.28, \mathrm{c}=28.63$ & $\alpha=\beta=90^{\circ}, \gamma=120^{\circ}$, & 6.742 & & {$[45]$} \\
\hline Germanium antimony telluride & 4.7 & Trigonal (hexagonal axes) & $\mathrm{R}-3 \mathrm{~m}$ & $\mathrm{a}=\mathrm{b}=4.24, \mathrm{c}=41.29$ & $\alpha=\beta=90^{\circ}, \gamma=120^{\circ}$ & 6.465 & & {$[46]$} \\
\hline $\begin{array}{l}\text { Dicesium Potassium } \\
\text { Manganese }\end{array}$ & 3.2 & Tetragonal & $\mathrm{I} 4 / \mathrm{mmm}$ & $\mathrm{a}=\mathrm{b}=6.12, \mathrm{c}=8.98$ & $\alpha=\beta=\gamma=90^{\circ}$ & 4.669 & & [47] \\
\hline Sodium Nitrate & 1.4 & Trigonal (hexagonal axes) & $\mathrm{R}-3 \mathrm{~m}$ & $\mathrm{a}=\mathrm{b}=5.08, \mathrm{c}=8.86$ & $\alpha=\beta=90^{\circ}, \gamma=120^{\circ}$ & 2.128 & & [48] \\
\hline
\end{tabular}




\section{Conclusion}

In this paper, we realized a series of field and laboratory studies in order of determining, sampling and analyzing five sample rocks that were taken from the carbonates liasic cover of Tazekka paleozoic inlier, located in the noth eastern part of Middle Atlas domain of Morocco.

According to the result of ICP analysis of these five samples, we note that no occurrences of $(\mathrm{Pb})$ mineralization were detected, however the $(\mathrm{Zn})(\mathrm{Cu})$ and $(\mathrm{Fe})$ are present as clues of low concentration $(0.018-8 \%)$, except of SS04 which shows a high tenor of $\mathrm{Zn}(36 \%)$ and Iron $(\approx 2 \%)$. We mark that this sample is taken from Ain Aouda where an old mine of zinc as kind of strata is manifested, and for that reason we conclude and purpose that the existence of high tenors of $(\mathrm{Zn})$ and $(\mathrm{Fe})$ may be related to some extension of the principal ore body of Ain Aouda. For the precious metals, we note the existence considerable $(\mathrm{Ag})$ concentration $(2-4 \mathrm{ppm})$ associated to some gold mineralization (1-7ppm). For the $(\mathrm{Sb})$ we note an average of $282 \mathrm{ppm}$, with $34 \mathrm{ppm}$ of (W) and $164.6 \mathrm{ppm}$ of (Sn).

Elsewhere in terms of XRD analysis, we confirmed that the sample SS01 contains mainly calcite, manganocolumbite, tetrahedrite and freibergite. The percentages of these products are calculated by software and show respectively $(44.1 \%),(27.7 \%),(14.2 \%)$ and (14\%). The second sample SS02 assigns the existence of calcite, freibergite, sylvanite, antimony iodide, and stistaite, where the phase percentages manifest as $(50.8 \%),(16.5 \%)$, $(13.4 \%),(10.4 \%)$ and $(8.9 \%)$. The results of SS03 indicates that the product is mainly formed by calcite, tin (II) halide sulphates, barium iron selenide, tetrahedrite and zinc germanium \pm barite. In this sample, the phase estimation is conjointly $(61.3 \%),(14.9 \%),(6.2 \%),(5.1 \%),(5 \%),(4.1 \%)$ and $(3.3 \%)$.

For the sample SS04, we note the presence of five phases as kind of calcite, copper iron sulphide, krennerite, zinc telluride, antimony iodide and stistaite, and the related percentages are respectively $(46.2 \%),(16.3 \%),(10.9 \%)$, $(9.6 \%),(9.2 \%)$ and $(7.9 \%)$. Finally, the sample SS05 displays a set of calcite, iron (II) iodide, niobium sulphate, theoparacelsite, silver antimony telluride, germanium antimony telluride, dicesium potassium manganese and sodium nitrate. However, the related estimation phases of sample SS05 is reciprocally $(32.8 \%),(15.2 \%),(14.8 \%)$, $(12.5 \%),(8.9 \%),(6.6 \%),(4.7 \%),(3.2 \%)$, and $(1.4 \%)$.

Taking into account the results of the ICP and XDR analysis, in this work, we highlight the presence of metalliferous concentrations in the five samples taken from the dolomitic breccias of the lower Lias in the MAGHRAWA region. These concentrations concern base metals whose $(\mathrm{Fe}),(\mathrm{Pb})$ and $(\mathrm{Zn})$ manifest as sulphate form, associated with supergeneous copper. On the other hand, we note that the precious metal including $(\mathrm{Ag}),(\mathrm{Au})$, and $\mathrm{Sb})$ are well developed and depends to the surface condition chemistry. It should be noted that other elements such as (Sn) have been detected in trace amounts.

In fact, the setting up of these metalliferous occurrences in the Mesozoic Liassic cover presents in a first-hand a concrete case of the evolution of the mineralization which is rich in $\mathrm{Fe}-\mathrm{Pb}-\mathrm{Zn}-\mathrm{Cu}-\mathrm{Ag}-\mathrm{Sb}-\mathrm{Sn}-\mathrm{W} . .$. , from the deep Hercynian basement up to its Liassic platform cover, and present in a second hand a new opportunity to conduct deep studies in terms of petrography, metallogeny, geophysics, and all disciplines of geology allowing the understanding of the distribution of these mineralization, and more precisely those of $(\mathrm{Ag}),(\mathrm{Au}),(\mathrm{Sb}),(\mathrm{Sn})$ which present new potential prospects for precious metals in the Tazekka Liassic cover.

\section{Acknowledgments}

Special thanks to the : Innovation city of USMBA (Morocco), ATLAS MINING company; Abdus Salam International; Center of Theoretical Physics (Trieste-Italy) and Africa Graphene Center; Nanosciences African Network, University of South Africa Department of Physics, iThemba Labs (South Africa), African Laser Center.

\section{REFERENCES}

[1] G.Sutter G. Carte structurale de la chaîne rifaine à 1/500 000 . Notes et Mém. Serv. Géol. Maroc, (1980).

[2] J. Aaujjar. Les minéralisations $\mathrm{Pb}-\mathrm{Zn}(\mathrm{Cu}) \mathrm{Fe} \mathrm{Ba}$ du Lias et du substratum paléozoïque sur la bordure orientale du massif du Tazekka (région de Taza, Maroc oriental), Thèse 3ème cycle Univ Paris 6, 233, 1987.

[3] J. Auajjar. Etude geologique et geochimique des mineralisations $\mathrm{Pb}-\mathrm{Zn}$ du district du Tazekka (region de Taza, Maroc oriental). Implications metallogeniques. doctoral Dissertation, University of Oujda, 90-300, 1994.

[4] J. Auajjar,J.R. Disnar, and J.C. Macquar. Origine et maturite' de la matie' re organique associe' e aux mine' ralisations sulfure' es $\mathrm{Pb}-\mathrm{Zn}(\mathrm{Cu})$ de la bordure orientale liasique du massif du Tazekka (Maroc). In: Proceedings of the International Workshop on the Metallogeny of Lead and Zinc 6-8 October 1992, Rabat, Morocco, p33. Moroccan Ministry of Energy and Mines, Rabat, 1992.

[5] O. Belhaj. Les gîtes d'antimoine du massif du Tazekka (Maroc oriental). Notes et Mém. Serv. Géol. Maroc, 207-375, 1994.

[6] A. Bennouna, M. Benabbou, C. Hoepffner, F. Kharbouch \& N. Youbi. The carboniferous volcano-sedimentary depocentre of Tazekka Massif (Middle Atlas, Morocco): new observations and geodynamic implications. Journal of African Earth Science, Vol 39, issues 3-5, 359-368, 2004

[7] F. Chalot-Prat. Pétrogenèse d'un volcanisme 
intracontinental tardi-orogénique hercynien. Etude du complexe volcanique carbonifère du Tazekka et de zones volcaniques comparables dans le Mekkam et la région de Jerada, Thèse doctorat, Univ. P. \& M. Curie, Paris, Mém. Sci. Terre, $\mathrm{N}^{\circ}$ 9021, 32-283, 1990.

[8] H. Ajamay. Evolution tectono-métamorphique du NW du massif du Tazekka: implications métallogéniques. Thèse Doct., Fac. Sci. Rabat, 152 p, 2010.

[9] A. Michard, C. Ho, M. Soulaimani \& L. Baider. The Variscan Belt. In A. Michard, O. Saddiqi, A. Chalouan, A. Mouttaqi (Eds.), Continental Evolution: The Geology of Morocco. Lecture. Notes Earth Science, Springer, Berlin Heidelberg, Ver 1. No 116, 65-132, 2008.

[10] P.A. Baker, S.J. Burns. The occurrence and formation of dolomite in organic-rich continental margin sediments. American Association of Petroleum Geologists Bulletin, Vol 69, No 11, 1917-1930, 1985.

[11] G.R. Dix. Patterns of burial- and tectonically controlled dolomitization in an Upper Devonian fringing-reef complex; Leduc Formation, Peace River Arch area, Alberta, Canada. Journal of Sedimentary Research, Vol 63, No 4, 628-640, 1993.

[12] J.M Gregg. On the formation and occurrence of saddle dolomite-discussion. J. Sedim. Petrol., 53, 1025-1026, 1983.

[13] J.M Gregg, and D.F Sibley. Epigenetic dolomitization and the origin of xenotopic dolomite texture. J. Sedim. Petrol., $54,710-724,1984$.

[14] M. Essamawal. Analyse tectonique et microtectonique du complexe volcano-sédimentaire carbonifère dans le massif hercynien du Tazekka (Moyen-Atlas, Maroc). Conséquences sur le contrôle structural de la minéralisation en antimoine de Boujaada. These 3ème cycle., Faculte. Sciences. Rabat, 184 p, 1999.

[15] C. Hoepffner, M.R Houari \& M. Bouabdelli : Tectonics of the North African Variscides (Morocco, western Algeria): an outline. Compte Rendus Geoscience, Vol 338, Issues1-2, 25-40, 2006

[16] D.L Leach, G.S Plumlee, A.H Hofstra, G.P Landis, E.L Rowan and J.G Viets. Origin of late dolomite cement by $\mathrm{CO} 2$ saturated deep basin brines: Evidence from the Ozark region, central United States, Geological Society of America, Geology Vol 19, No 4, 348-351, 1991.

[17] M.M Savard, G. Chi, T.Sami, A.E.Williams-Jones, and K. Leigh. Fluid inclusion and carbon, oxygen, and strontium isotope study of the Polaris Mississippi Valley-type $\mathrm{Zn}-\mathrm{Pb}$ deposit, Canadian Arctic Archipelago: implications for ore genesis. Mineral. Deposita Vol 35, No 6, 495-510, 2000.

[18] J.J Wilkinson and G. Earls. A high temperature hydrothermal origin for black dolomite matrix breccias in the Irish $\mathrm{Zn}-\mathrm{Pb}$ orefield. Cambridge University Press, Vol 64, No 6, 1017-1036, 2000.

[19] P. Morin. Les ressources minérales du massif du Tazekka et de ses bordures. Mines Géol., Rabat, Vol 10, 21-44, 1960.

[20] R. Schowengerdt. Remote sensing: models and methods for image processing (3rd ed.). Academic Press. p. 2. 2007.
[21] J. Choukrad, N. Saoud, M.A Elmoussalim, M. Charroud. The use of satellite images and remote sensing for the benefit of the extraction of lineament networks and the calculation of different indices of the Mesozoic coverage of the TAZEKKA Massif. (Maghraoua region). International Journal of Multidisciplinary science and Engineering, In progress.

[22] A. Montaser and D. W. Golightly. Inductively Coupled Plasmas in Analytical Atomic Spectrometry. VCH Publishers, Inc., New York, 1992.

[23] E. V. Shunko, D. E. Stevenson and V. S. Belkin, "Inductively Coupling Plasma Reactor With Plasma Electron Energy Controllable in the Range From $\$\{\backslash \operatorname{sim}\}\{6\} \$$ to $\$\{\backslash \operatorname{sim}\}\{\backslash \mathrm{rm} 100\} \sim\{\backslash \mathrm{rm} \mathrm{eV}\} \$, "$ in IEEE Transactions on Plasma Science, vol. 42, no. 3, pp. 774-785, March 2014

[24] I. Shafranovskii \& N.V Belov Paul Ewald (ed.)"E. S. Fedorov" (PDF). 50 Years of X-Ray Diffraction. Springer: 351. ISBN 90-277-9029-9. 1962.

[25] P. Ondrus, F. Veselovsky, A. Gabasova, J. Hlousek, V. Srein, I. Vavrnn, R. Skala, J. Sejkora, M. Drabek. Primary minerals of the Jachymov ore district, Journal of the Czech Geological Society, Vol.48, 19-147, 2003.

[26] S. C. Tarantino, M. Zema, M. Pistorino, M. C. Domeneghetti. High-temperature X-ray investigation of natural columbites, Physics and Chemistry of Minerals. Vol.30, 590-598, 2003.

[27] F. F. Foit, J. M. Hughes. Structural variations in mercurian tetrahedrite Sample E5 from the Spring Creek Claims in Harney County Oregon, American Mineralogist, Vol.89, 159-163, 2004.

[28] I. V. Rozhdestvenskaya, N. V. Zayakina, V. P. Samusikov. Crystal structure features of minerals from a series of tetrahedrite-freibergite Sample: 4, Mineralogiceskij Zhurnal, Vol.15, 9-17, 1993.

[29] S. M. Antao, I. Hassan. Temperature dependence of the structural parameters in the transformation of aragonite to calcite, as determined from in situ synchrotron powder X-ray-diffraction data, The Canadian Mineralogist, Vol.48, 1225-1236, 2010

[30] R. C. Peterson, I. Miller. Crystal structure and cation distribution in freibergite and tetrahedrite, Mineralogical Magazine, Vol.50, 717-721, 1986.

[31] G. Tunell, L. Pauling. The atomic arrangements and bonds of the gold-silver ditellurides, Acta Crystallographica, Vol.5, 375-381, 1952.

[32] L. G. Akselrud, M. Hanfland, U. Schwarz. Refinement of the crystal structure of Sb-I, at $2.22 \mathrm{GPa}$, - New Crystal Structures, Vol.218, 414-414, 2003.

[33] G. Hagg, A. G. Hybinette. X-ray studies on the systems of tin-antimony and tin-arsenic Locality: synthetic, The London Edinburgh and Dublin Philosophical Magazine and Journal of Science, Vol.20, 913-929, 1935.

[34] N. Ishizawa, H. Setoguchi, K. Yanagisawa. Structural evolution of calcite at high temperatures: Phase V unveiled, Scientific Reports, Vol.3, No.2832, 2013.

[35] J. D. Donaldson, S. M. Grimes. Novel tin(II) sites in X-ray crystal structures of the tin(II) halide sulphates K3Sn2 
(SO4) $3 \mathrm{X}(\mathrm{X}=\mathrm{Br}$ or $\mathrm{Cl})$, Journal of the Chemical Society. Dalton Transactions, Issue 7, 1301-1305, 1984.

[36] J. Caron, J. Neilson, D. Miller, A. Llobet, T. McQueen. Iron displacements and magnetoelastic coupling in the antiferromagnetic spin-ladder compound BaFe2Se3, Physical Review B, Vol.84, 180409, 2011.

[37] R. Kalbskopf. Strukturverfeinerung des Freibergits, Tschermaks Mineralogische und Petrographische Mitteilungen, Vol.18, 147-155, 1972.

[38] E. A. Vasilev, A. E. Gelyasin. Magnetic properties of the Mn1+x Sb1-x Snx system, Physica Status Solidi, Sectio A: Applied Research, Vol.47, K55-K57, 1978.

[39] F. Merlo, M. Pani, M. L. Fornasini. R M X compounds formed by alkaline earths, europium and ytterbium - II. Ternary phases with $\mathrm{M}=\mathrm{Zn}, \mathrm{Cd}$ and $\mathrm{X}=\mathrm{Si}, \mathrm{Ge}, \mathrm{Sn}, \mathrm{Pb}$, Journal of the Less-Common Metals, Vol.171, 329-336, 1991.

[40] R. Gross, N. Gross. Die Atomanordnung des Kupferkieses und die Struktur der Beruehrungsflaechen gesetzmaessig verwachsener Kristalle, Neues Jahrbuch fuer Mineralogie, Geologie und Palaeontologie. Beilage, Vol.48, 113-135, 1923.

[41] F. Pertlik. Crystal chemistry of natural tellurides II: Redetermination of the crystal structure of krennerite, (Au1$\mathrm{xAgx}) \mathrm{Te} 2$ with $\mathrm{x} \sim 0.2$ Locality: Sacaramb, Romania, Tschermaks Mineralogische und Petrographische Mitteilungen, Vol.33, 253-262, 1984.

[42] W. H. Zachariasen. Die Kristallstruktur der Telluride von Zink, Cadmium und Quecksilber, Norsk Geologisk Tidsskrift, Vol.8, 302-306, 1926.

[43] H. Sarp, R. Cerny. Theoparacelsite, Cu3(OH)2As2O7, a new mineral: its description and crystal structure, Archives des Sciences, Vol.54, 7-14, 2001.

[44] K. L. Moran, T. E. Gier, W. T. A. Harrison, G. D. Stucky, H. Eckert, K. Eichele, R. E. Wasylishen. Synthesis and characterization of mixed $\mathrm{ZnSe} / \mathrm{GaP}$ semiconductor species included in the sodalite structure, Journal of the American Chemical Society, Vol.115, 10553-10558, 1993.

[45] K. M. Ok, N. S. P. Bhuvanesh, P. S. Halasyamani. Sb Sbx M1-x O4 (M = Nb (V) or Ta (V)): solid solution behavior and second-harmonic generating properties, Journal of Solid State Chemistry, Vol.161, 57-62, 2001

[46] M. N. Schneider, M. Seibald, O. Oeckler. A new series of long-range ordered metastable phases in the system $\mathrm{M}-\mathrm{Sb}-\mathrm{Te}(\mathrm{M}=\mathrm{Ge}, \mathrm{Ag})$, Dalton Transactions, Issue 11, 2004-2011, 2009.

[47] S. Welzmiller, T. Rosenthal, P. Ganter, L. Neudert, F. Fahrnbauer, P. Urban, C. Stiewe, J. de Boor, O. Oeckler. Layered germanium tin antimony tellurides: element distribution, nanostructures and thermoelectric properties, Dalton transactions, Vol.43, 10529-10540, 2014.

[48] Y. Xu, K. Soederberg, R. Norrestam. High-pressure phase transition in Cs2 K Mn F6, Journal of Solid State Chemistry, Vol.153, 248-253, 2000.

[49] G. Gonschorek, H. Weitzel, G. Miehe, H. Fuess, W. W. Schmahl. The crystal structures of Na N O3 at $100 \mathrm{~K}, 120 \mathrm{~K}$, and $563 \mathrm{~K}$, Zeitschrift für Kristallographie, Vol.215, 752-756, 2000.

[50] R. Huang, Y. Shen, L. Zhao, M. Yan. Effect of hydrothermal temperature on structure and photochromic properties of WO3 powder, Advanced Powder Technology, Vol.23, 211-214, 2012. 